\title{
PENGARUH DUKUNGAN PEMBEKALAN PANGKALAN TNI ANGKATAN LAUT TERHADAP OPERASI PENGAMANAN PERBATASAN
}

\author{
Constantius Rusmaji 1) \\ 1) Program Studi Magister Operasi Laut Pendidikan Reguler Angkatan ke-57 \\ Sekolah Staf dan Komando TNI Angkatan Laut Jakarta \\ Email: constantius_rusmaji@tnial.mil.id
}

Edi Suhardono ${ }^{2)}$

2) Wakil Dekan Fakultas Strategi Pertahanan

Universitas Pertahanan Bogor

\begin{abstract}
This study explains the support variables for Naval Base supplies for border security operations. The research method used is a quantitative method by distributing questionnaire.The number of samples taken was 80 samples from the total population of 371 persons. The research was carried out starting from the classification of samples respondents based on gender, age, education and years of service. The research variables in this study are supporting variables in the supply as independent variables $(X)$ and border security operations variables as cooperation variables $(Y)$. Indicators for variable $X$ include: personnel involved in the supply, infrastructure for the supply of equipment, supporting facilities for the supplies and types of supplies that can be supported. While indicators on the $Y$ variables include: personnel involved in the operation, operating facilities, area of operation and duration of operation. The data analysis process is carried out with several tests, among others: validity test, namely testing the data analysis process to determine whether the research instrument is valid or not. The next test is the reliability test, the data analysis process to answer the accuracy of the research instruments. The normality of the trial is tested. The next data analysis process is the hypothesis test in the regression test. Regression test is a process of analyzing data to study the influence between research variables. The regression test conducted in this study is a partial regression test because the independent variable used is one variable. After it was implemented, everything was proven. Supports provisioning variables. Naval Base determines positive and significant impact on border security operations.
\end{abstract}

Keywords: Naval base, debriefing support, border security operations

\section{PENDAHULUAN}

Pangkalan TNI Angkatan Laut sebagai bagian dari komponen Sistem Senjata Armada Terpadu (SSAT), harus dapat melaksanakan fungsinya untuk memberikan dukungan logistik secara optimal terhadap kelancaran operasional komponen SSAT lainnya yaitu kapal, pesawat udara dan Marinir. Bentuk dukungan yang dimaksud berupa Fasilitas Labuh (Faslabuh) baik laut maupun udara, Fasilitas Pemeliharaan dan Perbaikan (Fasharkan), Fasilitas Pembekalan (Fasbek), Fasilitas Perawatan Personel (Faswatpers) dan Fasilitas Pembinaan Pangkalan (Fasbinlan).

Pangkalan TNI Angkatan Laut dalam fungsi Fasbek, mempunyai kewajiban mendukung kebutuhan logistik perbekalan kepada KRI yang beroperasi di wilayah kerjanya termasuk KRI yang melaksanakan Operasi Pengamanan Perbatasan. Hal itu membutuhkan kesiapan personel dalam pelaksanaan tugas memberikan 
dukungan logistik dihadapkan dengan keterbatasan yang ada di Pangkalan TNI Angkata Laut.

Berdasarkan latar belakang tersebut peneliti tertarik melaksanakan penelitian mengenai pengaruh dukungan pembekalan Pangkalan TNI Angkatan Laut terhadap Operasi Pengamanan Perbatasan. Dapat diidentifikasi permasalahan yang ada dalam pelaksanaan pembinaan dukungan pembekalan di Pangkalan TNI Angkatan Laut yaitu Dukungan Fasilitas Pembekalan (Fasbek) Pangkalan TNI Angkatan Laut yaitu keterbatasan personel serta sarana dan prasarana pembekalan.

Tujuan penelitian ini adalah untuk menganalisis pengaruh dukungan pembekalan Pangkalan TNI Angkatan Laut terhadap Operasi Pengamanan Perbatasan.

\section{METODE PENELITIAN}

Penelitian ini akan dilakukan dengan metode analisis kuantitatif dengan tujuan mengetahui pengaruh dukungan pembekalan Pangkalan TNI Angkatan Laut terhadap Operasi Pengamanan Perbatasan. Populasi 371 personil dengan sampel 80 personil, metode analisis regresi sederhana dan berganda.

\section{LANDASAN TEORI}

\section{Teori logistik Eccles}

Sesuai buku "Logistics in the National Defense" menjelaskan hubungan antara Strategi-Logistik-Taktik. Strategi terkait dengan penentuan dan agenda pencapaian logistik berdasarkan penciptaan dan penyelenggaraan dukungan secara terus-menerus kepada satuan tempur dan satuan taktis demi tercapainya tujuan strategi. Srategi dan taktik memberikan pola penyelenggaraan operasi militer, sedangkan logistik mengadakan sarananya. Strategi dan taktik adalah cara yang digunakan oleh pemimpin untuk mencapai tujuan dari suatu kegiatan militer yaitu memenangkan peperangan. Untuk maksud tersebut selain strategi dan taktik, satu hal yang dominan dan sangat menunjang tercapainya kemenangan adalah dukungan logistik yang memadai bagi personel maupun peralatan yang digunakan. Ketiga unsur tersebut merupakan hal yang tidak dapat dipisahkan karena ketiganya saling mempengaruhi. (Eccles, 1959).

Logistik TNI Angkatan Laut adalah seluruh kegiatan yang bertujuan untuk menyiapkan dan menyediakan materiil serta penyelenggaraan dukungan logistik (duklog) yang dibutuhkan dan digunakan dalam penyelenggaraan seluruh sistem pembinaan TNI Angkatan Laut sehingga dapat mewujudkan kekuatan yang mampu melaksanakan tugas-tugas TNI Angkatan Laut. ${ }^{1}$

Teori logistik yaitu logistik militer khususnya Logistik TNI Angkatan Laut untuk mengetahui sejauh mana dukungan logistik Pangkalan TNI Angkatan Laut yang salah satunya adalah dukungan pemeliharaan berpengaruh terhadap operasi di wilayah kerja pangkalan tersebut.

\section{Teori Sea Power Mahan}

Enam elemen Sea Power yang dapat membuat kemakmuran dan kebesaran sebuah bangsa atau negara di laut adalah Geographical Position, Phisical Conformation, Extent of Territory, Number of Population, National Character, Character of Government (Mahan, 1890).

Pada elemen pertama Geographical Position dijelaskan bahwa posisi geografi suatu negara akan sangat menentukan bagi kejayaan bangsa tersebut dimana posisi tersebut dapat memberikan keuntungan strategis atau tidak .

Sementara lemen kedua Phisical Conformation menjelaskan jumlah dan kedalaman pelabuhan yang dimiliki oleh suatu negara merupakan sumber kekuatan 
dan kemakmuran namun sebaliknya bahwa ini juga akan menjadi kelemahan saat angkatan laut negara tersebut tidak dapat menjaga wilayahnya dengan baik. Musuh akan mempunyai banyak akses untuk menyerang negara tersebut. .

Elemen ketiga Extent of Territory mengatakan kalau panjang garis pantai dan karakter pelabuhan merupakan sumber kekuatan suatu negara. Hal tersebut juga dapat menjadi kelemahan saat garis pantai yang dimilikinya tidak ada populasi yang tinggal di daerah tersebut. Pada elemen keempat Number of Population dijelaskan saat masyarakat sudah berorientasi maritim maka berapa banyak tenaga pelaut yang dapat disiapkan termasuk berapa banyak armada kapal yang dapat dibangun dengan cepat untuk menggerakkan perekonomian.

Elemen kelima National Character menjelaskan bahwa karakter dari populasi secara keseluruhan merupakan bentuk karakter dari pemerintahan sebuah negara. Saat sebuah negara tidak memiliki karakter kelautan yang kuat, maka secara keseluruhan hal tersebut akan berdampak pada populasi yang ada. Karakter nasional yang kuat untuk membangun kekuatan lautnya baik melalui perdagangan maupun pengembangan kekuatan angkatan lautnya merupakan hal dasar untuk dapat menjadi sebuah negara yang besar.

Pada elemen keenam Character of Government dijelaskan bahwa kebijakan pemerintah akan mempengaruhi pengembangan kekuatan laut negara tersebut. Kebijakan pemerintah ini vital bagi sebuah negara, tanpa adanya kebijakan yang berorientasi maritim maka mustahil negara tersebut dapat berkembang kekuatan lautnya.

Teori Sea Power Mahan dijadikan acuan oleh peneliti untuk mengetahui pelaksanaan operasi pengamanan perbatasan di laut serta hal-hal yang mempengaruhi operasi tersebut salah satunya pengaruh dari dukungan logistik pangkalan seperti pada Operasi Pengamanan Perbatasan RI-Malaysia.

\section{PEMBAHASAN}

Pada penelitian ini, tahap pengolahan dimulai dengan pengumpulan kuesioner yang telah disebar kemudian dengan memasukkan data kuesioner ke dalam satu tabel (tabulasi data) ke melalui program Microsoft Excel. Data yang diperoleh setelah ditabulasi dikelompokkan sesuai variabel penelitian yaitu dukungan pembekalan Pangkalan TNI Angkatan Laut (X) dan Operasi Pengamanan Perbatasan (Y) Setelah data dalam program Excel didapatkan, data dimasukkan ke dalam program SPSS dan baru kemudian diolah dan dianalisa serta diuji.

\section{Variabel Dukungan Pembekalan}

Variabel dukungan pembekalan terdiri dari empat indikator yaitu, personel yang terlibat pembekalan, sarana prasarana pembekalan, fasilitas pendukung pembekalan dan jenis bekal yang mampu didukung.

\section{Personel yang terlibat pembekalan}

Pada indikator personel yang terlibat pembekalan, dari 80 responden, distribusi jawaban sebagai berikut: jawaban sangat setuju (SS) sebanyak 7 responden, jawaban setuju (S) sebanyak 33 responden, jawaban netral (N) sebanyak 19 responden dan jawaban tidak setuju (TS) sebanyak 21 responden. Data dapat dilihat pada tabel 1 di bawah ini: 
Tabel 1. Indikator Personel yang Terlibat Pembekalan

\begin{tabular}{|c|c|c|c|c|c|}
\hline \multicolumn{6}{|c|}{ Pembekalan 1} \\
\hline Ketera & & Frequency & Percent & $\begin{array}{c}\text { Valid } \\
\text { Percent }\end{array}$ & $\begin{array}{c}\text { Cumulative } \\
\text { Percent }\end{array}$ \\
\hline$\overline{\text { Valid }}$ & $2(\mathrm{TS})$ & 21 & 26.3 & 26.3 & 26.3 \\
\hline & $3(\mathrm{~N})$ & 19 & 23.8 & 23.8 & 50.0 \\
\hline & $4(S)$ & 33 & 41.3 & 41.3 & 91.3 \\
\hline & $5(\mathrm{SS})$ & 7 & 8.8 & 8.8 & 100.0 \\
\hline & Total & 80 & 100.0 & 100.0 & \\
\hline
\end{tabular}

Sumber: Hasil Pengolahan Data Peneliti, 2019.

\section{Sarana prasarana pembekalan}

Pada sarana prasarana pembekalan, dari 80 responden, distribusi jawaban sebagai berikut: jawaban sangat setuju (SS) sebanyak 6 responden, jawaban setuju (S) sebanyak 26 responden, jawaban netral $(\mathrm{N})$ sebanyak 33 responden dan jawaban tidak setuju (TS) sebanyak 15 responden. Data dapat dilihat pada tabel 2 di bawah ini:

Tabel 2. Indikator Sarana Prasarana Pembekalan

\begin{tabular}{lccccc}
\hline \multicolumn{5}{c}{ Pembekalan 2 } & \\
\hline \multicolumn{1}{l}{ Keterangan } & Frequency & Percent & Palid & Percent & Percent \\
\hline Valid & $2(\mathrm{TS})$ & 15 & 18.8 & 18.8 & 18.8 \\
& $3(\mathrm{~N})$ & 33 & 41.3 & 41.3 & 60.0 \\
& $4(\mathrm{~S})$ & 26 & 32.5 & 32.5 & 92.5 \\
& $5(\mathrm{SS})$ & 6 & 7.5 & 7.5 & 100.0 \\
\hline & Total & $\mathbf{8 0}$ & $\mathbf{1 0 0 . 0}$ & $\mathbf{1 0 0 . 0}$ & \\
\hline
\end{tabular}

Sumber: Hasil Pengolahan Data Peneliti, 2019.

Fasilitas pendukung pembekalan

Pada indikator fasilitas pendukung pembekalan, dari 80 responden, distribusi jawaban sebagai berikut: jawaban sangat setuju (SS) sebanyak 8 responden, jawaban setuju (S) sebanyak 24 responden, jawaban netral (N) sebanyak 37 responden dan jawaban tidak setuju (TS) sebanyak 11 responden. Data dapat dilihat pada tabel 3 di bawah ini: 
Tabel 3. Indikator Fasilitas Pendukung Pembekalan

\begin{tabular}{|c|c|c|c|c|c|}
\hline \multicolumn{6}{|c|}{ Pembekalan 3} \\
\hline \multicolumn{2}{|c|}{ Keterangan } & Frequency & Percent & $\begin{array}{c}\text { Valid } \\
\text { Percent }\end{array}$ & $\begin{array}{c}\text { Cumulative } \\
\text { Percent }\end{array}$ \\
\hline \multirow{5}{*}{ Valid } & 2 (TS) & 11 & 13.8 & 13.8 & 13.8 \\
\hline & $3(\mathrm{~N})$ & 37 & 46.3 & 46.3 & 60.0 \\
\hline & $4(S)$ & 24 & 30.0 & 30.0 & 90.0 \\
\hline & $5(\mathrm{SS})$ & 8 & 10.0 & 10.0 & 100.0 \\
\hline & Total & 80 & 100.0 & 100.0 & \\
\hline
\end{tabular}

Sumber: Hasil Pengolahan Data Peneliti, 2019

Jenis bekal yang mampu didukung

Pada indikator jenis bekal yang mampu didukung, dari 80 responden, distribusi jawaban sebagai berikut: jawaban sangat setuju (SS) sebanyak 5 responden, jawaban setuju (S) sebanyak 28 responden, jawaban netral $(\mathrm{N})$ sebanyak 38 responden dan jawaban tidak setuju (TS) sebanyak 9 responden. Data dapat dilihat pada tabel 4 di bawah ini:

Tabel 4. Indikator Jenis Bekal yang Mampu Didukung

\begin{tabular}{|c|c|c|c|c|c|}
\hline \multicolumn{6}{|c|}{ Pembekalan 4} \\
\hline \multicolumn{2}{|c|}{ Keterangan } & Frequency & Percent & $\begin{array}{c}\text { Valid } \\
\text { Percent }\end{array}$ & $\begin{array}{c}\text { Cumulative } \\
\text { Percent }\end{array}$ \\
\hline \multirow[t]{5}{*}{ Valid } & $2(\mathrm{TS})$ & 9 & 11.3 & 11.3 & 11.3 \\
\hline & $3(\mathrm{~N})$ & 38 & 47.5 & 47.5 & 58.8 \\
\hline & $4(S)$ & 28 & 35.0 & 35.0 & 93.8 \\
\hline & $5(\mathrm{SS})$ & 5 & 6.3 & 6.3 & 100.0 \\
\hline & Total & 80 & 100.0 & 100.0 & \\
\hline
\end{tabular}

Sumber: Hasil Pengolahan Data Peneliti, 2019

\section{Variabel Operasi Pengamanan Perbatasan \\ Variabel operasi pengamanan perbatasan terdiri dari empat indikator yaitu, personel yang terlibat operasi, sarana operasi, wilayah operasi dan durasi/lama operasi yang bisa dilaksanakan.}

\section{Personel yang terlibat operasi}

Pada indikator personel yang terlibat operasi, dari 80 responden, distribusi jawaban sebagai berikut: jawaban sangat setuju (SS) sebanyak 9 responden, jawaban setuju (S) sebanyak 49 responden, jawaban netral $(\mathrm{N})$ sebanyak 14 responden dan jawaban tidak setuju (TS) sebanyak 8 responden. Data dapat dilihat pada tabel 5 di bawah ini: 
Tabel 5. Personel yang Terlibat Operasi

\begin{tabular}{llcccc}
\hline \multicolumn{5}{c}{ Ops. Pamtas 1 } \\
\hline \multicolumn{1}{l}{ Keterangan } & Frequency & Percent & $\begin{array}{c}\text { Valid } \\
\text { Percent }\end{array}$ & $\begin{array}{c}\text { Cumulative } \\
\text { Percent }\end{array}$ \\
\hline Valid & $2(\mathrm{TS})$ & 8 & 10.0 & 10.0 & 10.0 \\
& $3(\mathrm{~N})$ & 14 & 17.5 & 17.5 & 27.5 \\
& $4(\mathrm{~S})$ & 49 & 61.3 & 61.3 & 88.8 \\
& $5(\mathrm{SS})$ & 9 & 11.3 & 11.3 & 100.0 \\
\hline & Total & $\mathbf{8 0}$ & $\mathbf{1 0 0 . 0}$ & $\mathbf{1 0 0 . 0}$ & \\
\hline
\end{tabular}

Sumber: Hasil Pengolahan Data Peneliti, 2019.

\section{Sarana operasi}

Pada indikator sarana operasi, dari 80 responden, distribusi jawaban sebagai berikut: jawaban sangat setuju (SS) sebanyak 10 responden, jawaban setuju (S) sebanyak 34 responden, jawaban netral (N) sebanyak 20 responden dan jawaban tidak setuju (TS) sebanyak 16 responden. Data dapat dilihat pada tabel 6 di bawah ini:

Tabel 6. Sarana Operasi

\begin{tabular}{llcccc}
\hline \multicolumn{5}{c}{ Ops. Pamtas 2 } \\
\hline \multicolumn{4}{l}{ Keterangan } & \multicolumn{4}{c}{ Valid } & Cumulative \\
\hline Valid & Frequency & Percent & Percent & Percent \\
\hline & 3 (N) & 16 & 20.0 & 20.0 & 20.0 \\
& $4(\mathrm{~S})$ & 20 & 25.0 & 25.0 & 45.0 \\
& $5(\mathrm{SS})$ & 10 & 42.5 & 42.5 & 87.5 \\
\cline { 2 - 6 } Total & $\mathbf{8 0}$ & $\mathbf{1 0 0 . 0}$ & $\mathbf{1 0 0 . 0}$ & \\
\hline
\end{tabular}

Sumber: Hasil Pengolahan Data Peneliti, 2019.

\section{Wilayah Operasi}

Pada indikator wilayah operasi, dari 80 responden, distribusi jawaban sebagai berikut: jawaban sangat setuju (SS) sebanyak 10 responden, jawaban setuju (S) sebanyak 27 responden, jawaban netral (N) sebanyak 28 responden dan jawaban tidak setuju (TS) sebanyak 15 responden. Data dapat dilihat pada tabel 7 di bawah ini:

Tabel 7. Wilayah Operasi

\begin{tabular}{llcccc}
\hline \multicolumn{5}{c}{ Ops. Pamtas 3 } \\
\hline \multirow{6}{*}{ Keterangan } & Frequency & Percent & Percent & Pumulative \\
Valid & 2 (TS) & 15 & 18.8 & 18.8 & 18.8 \\
& $3(\mathrm{~N})$ & 28 & 35.0 & 35.0 & 53.8 \\
& $4(\mathrm{~S})$ & 27 & 33.8 & 33.8 & 87.5 \\
& $5(\mathrm{SS})$ & 10 & 12.5 & 12.5 & 100.0 \\
\hline & Total & $\mathbf{8 0}$ & $\mathbf{1 0 0 . 0}$ & $\mathbf{1 0 0 . 0}$ & \\
\hline
\end{tabular}

Sumber: Hasil Pengolahan Data Peneliti, 2019 


\section{Durasi/Lama Waktu Operasi}

Pada indikator durasi/lama operasi, dari 80 responden, distribusi jawaban sebagai berikut: jawaban sangat setuju (SS) sebanyak 9 responden, jawaban setuju (S) sebanyak 50 responden, jawaban netral (N) sebanyak 16 responden dan jawaban tidak setuju (TS) sebanyak 5 responden. Data dapat dilihat pada tabel 8 di bawah ini:

Tabel 8. Durasi/Lama Operasi

\begin{tabular}{|c|c|c|c|c|c|}
\hline \multicolumn{6}{|c|}{ Ops. Pamtas 4} \\
\hline \multicolumn{2}{|c|}{ Keterangan } & Frequency & Percent & $\begin{array}{l}\text { Valid } \\
\text { Percent }\end{array}$ & $\begin{array}{c}\text { Cumulative } \\
\text { Percent }\end{array}$ \\
\hline Valid & $2(\mathrm{TS})$ & 5 & 6.3 & 6.3 & 6.3 \\
\hline & $3(\mathrm{~N})$ & 16 & 20.0 & 20.0 & 26.3 \\
\hline & $4(\mathrm{~S})$ & 50 & 62.5 & 62.5 & 88.8 \\
\hline & $5(\mathrm{SS})$ & 9 & 11.3 & 11.3 & 100.0 \\
\hline & Total & 80 & 100.0 & 100.0 & \\
\hline
\end{tabular}

Sumber: Hasil Pengolahan Data Peneliti, 2019.

Analisis data dilakukan dalam dua tahap yaitu dengan pengujian prasyarat analisis dan tahap berikutnya analisis lanjut sebelum dillaksanakan pengujian hipotesis.

\section{Uji Validitas}

Uji Validitas digunakan untuk mengukur sah atau valid tidaknya suatu kuesioner. Syarat minimum dianggap butir instrumen valid pada penelitian ini adalah nilai indeks validitasnya memiliki $\mathrm{r}$ hitung $>\mathrm{r}$ tabel atau $\mathrm{r}$ hitung $>0,360$ sebagaimana dapat dilihat pada tabel-tabel berikut ini:

Tabel 9. Hasil Uji Validitas Varibel Pembekalan

\begin{tabular}{|c|c|c|c|c|c|c|}
\hline \multicolumn{7}{|c|}{ Correlations } \\
\hline & & X2_1 & X2_2 & X2_3 & X2_4 & $\mathbf{X 2}$ \\
\hline \multirow[t]{3}{*}{$\overline{X \_1}$} & Pearson Correlation & 1 &, $756^{* *}$ &, $617^{* *}$ & $487^{* *}$ &, $887^{* *}$ \\
\hline & Sig. (2-tailed) & &, 000 & 000 &, 000 & 000 \\
\hline & $\mathrm{N}$ & 80 & 80 & 80 & 80 & 80 \\
\hline \multirow[t]{3}{*}{$\overline{X \_2}$} & Pearson Correlation &, $756^{* *}$ & 1 &, $583^{* *}$ &, $548^{* *}$ &, $884^{* *}$ \\
\hline & Sig. (2-tailed) &, 000 & & 000 &, 000 & 000 \\
\hline & $\mathrm{N}$ & 80 & 80 & 80 & 80 & 80 \\
\hline \multirow[t]{3}{*}{ X_3 } & Pearson Correlation &, $617^{\text {*** }}$ &, $583^{* *}$ & 1 & $431^{* *}$ &, $796^{* *}$ \\
\hline & Sig. (2-tailed) & 000 & 000 & &, 000 & 000 \\
\hline & $\mathrm{N}$ & 80 & 80 & 80 & 80 & 80 \\
\hline \multirow[t]{3}{*}{ X_4 } & Pearson Correlation &, $487^{* *}$ &, $548^{* *}$ &, $431^{* * *}$ & 1 &, $723^{* *}$ \\
\hline & Sig. (2-tailed) & ,000 & ,000 &, 000 & & ,000 \\
\hline & $\mathrm{N}$ & 80 & 80 & 80 & 80 & 80 \\
\hline \multirow[t]{3}{*}{$\mathrm{X}$} & Pearson Correlation &, $887^{* *}$ & $884^{* *}$ &, $796^{* *}$ & $723^{* *}$ & 1 \\
\hline & Sig. (2-tailed) & ,000 & 000 &, 000 &, 000 & \\
\hline & $\mathrm{N}$ & 80 & 80 & 80 & 80 & 80 \\
\hline
\end{tabular}




\section{Uji Reliabilitas.}

Tabel 10. Hasil Uji Validitas Variabel Ops. Pamtas

\begin{tabular}{|c|c|c|c|c|c|c|}
\hline & & Y1 & Y2 & Y3 & Y4 & $Y$ \\
\hline & & orrelati & ons & & & \\
\hline $\mathrm{Y} 1$ & Pearson Correlation & 1 & $469^{* *}$ &, $451^{* *}$ & 211 &, $741^{* *}$ \\
\hline & Sig. (2-tailed) & &, 000 & ,000 & ,061 &, 000 \\
\hline & $\mathrm{N}$ & 80 & 80 & 80 & 80 & 80 \\
\hline $\bar{Y} 2$ & Pearson Correlation & $469^{\text {*** }}$ & 1 &, $479^{* *}$ & $295^{\text {*** }}$ &, $812^{* *}$ \\
\hline & Sig. (2-tailed) &, 000 & & ,000 & ,008 & 000 \\
\hline & $\mathrm{N}$ & 80 & 80 & 80 & 80 & 80 \\
\hline$\overline{\mathrm{Y} 3}$ & Pearson Correlation &, $451^{* *}$ &, $479^{* *}$ & 1 & , 127 &, $753^{* *}$ \\
\hline & Sig. (2-tailed) &, 000 &, 000 & & ,261 &, 000 \\
\hline & $\mathrm{N}$ & 80 & 80 & 80 & 80 & 80 \\
\hline$\overline{Y 4}$ & Pearson Correlation & ,211 &, $295^{* *}$ & ,127 & 1 &, $527^{* *}$ \\
\hline & Sig. (2-tailed) & 061 & ,008 & 261 & &, 000 \\
\hline & $\mathrm{N}$ & 80 & 80 & 80 & 80 & 80 \\
\hline$\overline{\mathrm{Y}}$ & Pearson Correlation &, $741^{* *}$ &, $812^{* *}$ &, $753^{* *}$ &, $527^{* *}$ & 1 \\
\hline & Sig. (2-tailed) & ,000 &, 000 &, 000 & ,000 & \\
\hline & $\mathrm{N}$ & 80 & 80 & 80 & 80 & 80 \\
\hline
\end{tabular}

**. Correlation is significant at the 0.01 level (2-tailed).

Sumber: Hasil Pengolahan Data Peneliti, 2019.

Tabel 11. Hasil Uji Realibilitas Variabel Pembekalan (X)

Case Processing Summary

\begin{tabular}{llcr}
\hline & $\mathrm{N}$ & $\%$ \\
\hline Cases & Valid & 80 & 100,0 \\
& Excluded $^{\mathrm{a}}$ & 0 &, 0 \\
& Total & 80 & 100,0 \\
\hline
\end{tabular}

Listwise deletion based on all variables in the procedure.

Sumber: Hasil Pengolahan Data Peneliti, 2019. 


\section{Uji Normalitas}

Tabel 12. Hasil Uji Normalitas Variabel Pembekalan (X)

Tests of Normality

\begin{tabular}{lrcccccc}
\hline & \multicolumn{3}{c}{ Kolmogorov-Smirnov $^{\mathrm{a}}$} & \multicolumn{3}{c}{ Shapiro-Wilk } \\
\cline { 2 - 8 } & Statistic & df & Sig. & Statistic & df & Sig. \\
\hline Pembekalan &, 093 & 80 &, 084 &, 967 & 80 &, 036 \\
\hline
\end{tabular}

Lilliefors Significance Correction

Sumber: Hasil Pengolahan Data Peneliti, 2019.

Tabel 13. Hasil Uji Normalitas Variabel Operasi Pamtas (Y)

Tests of Normality

\begin{tabular}{lrrrrrr}
\hline & \multicolumn{3}{c}{ Kolmogorov-Smirnov $^{\mathrm{a}}$} & \multicolumn{3}{c}{ Shapiro-Wilk } \\
\cline { 2 - 8 } & Statistic & df & \multicolumn{1}{c}{ Sig. } & Statistic & df & \multicolumn{1}{c}{ Sig. } \\
\hline Ops.Pamtas &, 091 & 80 &, 096 &, 980 & 80 &, 238 \\
\hline
\end{tabular}

Lilliefors Significance Correction

Sumber: Hasil Pengolahan Data Peneliti, 2019

Dari tabel statistik di atas, terlihat bahwa model regresi untuk variabel dukungan pembekalan berdistribusi normal yaitu dengan Asymp. Sig. sebesar 0,084 $(>0,05)$ dan untuk variabel operasi pamtas juga berdistribusi normal yaitu dengan Asymp. Sig. sebesar 0,096 (>0,05).

\section{Pengujian Hipotesis}

Hipotesis awal penelitian untuk variabel dukungan pembekalan Pangkalan TNI AL H0: tidak terdapat pengaruh yang signifikan antara dukungan pembekalan Pangkalan TNI AL terhadap operasi pengamanan perbatasan.

$\mathrm{H1}$ : terdapat pengaruh yang signifikan antara dukungan pembekalan Pangkalan TNI AL terhadap operasi pengamanan perbatasan.

Variabel dukungan pembekalan apakah dapat mempengaruhi operasi pamtas, dapat dilihat dari tabel 14 di bawah ini.

Tabel 14. Koefisien Regresi $X$ terhadap $Y$

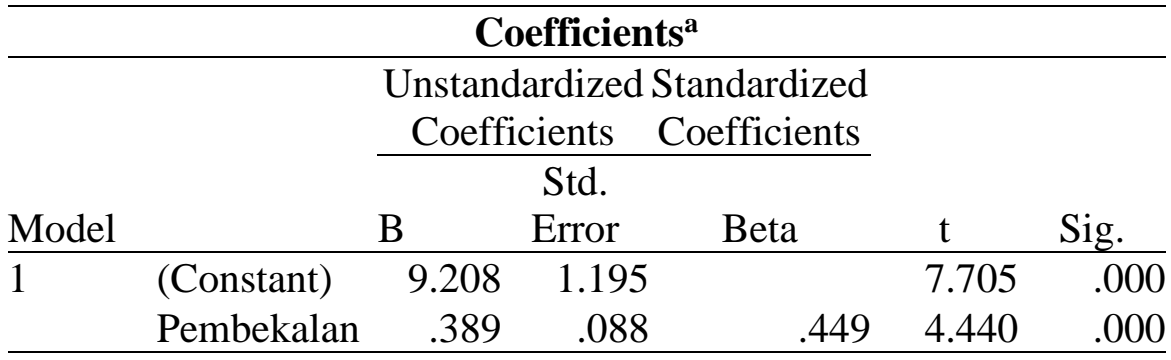

a. Dependent Variable: Ops.Pamtas

Sumber: Hasil Pengolahan Data Peneliti, 2019.

Berdasarkan hasil pengolahan data, diperoleh nilai $\mathrm{t}$ hitung adalah 4,440, sedangkan nilai $\mathrm{t}$ tabel dengan 80 responden sebesar 1.66462 menyatakan 
bahwa variabel dukungan pembekalan berpengaruh positif dan signifikan terhadap variabel operasi pamtas. Dari data pada tabel, persamaan regresi yang dihasilkan yaitu

$$
\mathbf{Y}=\mathbf{9 , 2 0 8}+\mathbf{0 , 3 8 9}(\mathrm{X} 2)+\mathrm{e}
$$

Nilai positif 0,389 dalam koefisien regresi variabel dukungan pembekalan menunjukkan hubungan positif artinya pembekalan dapat meningkatkan operasi pamtas.

\section{KESIMPULAN DAN SARAN}

\section{Kesimpulan}

Sebagai langkah akhir dalam penelitian ini adalah mengambil kesimpulan atas hasil pengujian hipotesis dan pembahasan. Berdasarkan hasil analisis dan pengujian hipotesis diperoleh bahwa variabel dukungan pembekalan Pangkalan TNI Angkatan Laut berpengaruh positif dan signifikan terhadap operasi pengamanan perbatasan.

\section{Saran}

Hendaknya Mabes TNI Angkatan Laut melengkapi sarana dan prasarana dukungan pembekalan di Pangkalan TNI Angkatan Laut khususnya gudang dan personel pengawak dukungan pembekalan Pangkalan TNI Angkatan Laut demi lancarnya pelaksanaan dukungan pembekalan bagi unsur-unsur TNI Angkatan Laut yang beroperasi di wilayah kerjanya khususnya yang melaksanakan operasi pengamanan perbatasan.

\section{DAFTAR PUSTAKA}

Bungin, Burhan (2004). Metodologi Penelitian Kuantitatif, Surabaya : Permada Media

Dadang, S. (2016). Kamus Besar Bahasa Indonesia. Kemendikbud RI.

Dhilon, B. S., (2006). Maintainability, Maintenance and Reliability for Engineers, New York. Taylor and Francis Group.
Eccles, Henry E.(1959). Logistics in The National Defense. The Stackpole Company Harrisburg, Pennsylvania.

Edy Sutrisno, (2011). Manajemen Sumber Daya Manusia, Jakarta: Kencana, Cet.ke-3

Hasan M. Iqbal, (2002). Pokok-pokok Metodologi Penelitian dan Aplikasinya. Bogor, Ghalia Indonesia,

Iskandar, (2009). Metodologi Penelitian Pendidikan dan Sosial, (Kuantitatif dan Kualitatif). Jakarta: GP Press.

Mahan, Alfred Thayer (1890). The Influence of Sea Power Upon History 1660-1783. Little, Brown Company: Boston

Muthis, Robert L, \& Jackson, John H,(2006). Human Resource Management, Jakarta: Salemba Empat,

Nana Syaodih Sukmadinata, (2012). Metode Penelitian Pendidikan, Bandung: PT Remaja Rosdakarya

Riduwan, (2006). Metode dan Teknik Menyusun Tesis, Bandung: Alfabeta,

Subana \& Moersetyo Rahadi, (2005). Statistik Pendidikan, Bandung: Pustaka Seni

Sugiyono, (2008). Metode Penelitian Bisnis. Bandung: Alfabet,

Sugiyono. (2013.) Metode Penelitian Pendidikan : Pendekatan Kuantitatif, Kualitatif, dan $R \& D$. Bandung: Alfabet.

Suharsimi Arikunto, (2002). Prosedur Penelitian Suatu Pendekatan Praktik, Jakarta: PT Rineka Cipta,

Taliziduhu Ndrah, (1997). Pengantar Teori Pengembangan Sumber Daya Manusia, Jakarta: PT. Rineka Cipta

Tanzeh, Ahnmad (2011). Metode Penelitian Praktis, Yogyakarta: Teras,

Tulus, Winarsunu (2006). Statistik Dalam Penelitian Psikologi Dan Pendidikan, Malang: Universitas Muhamadiyah Malang, 
Zainal, Arifin (2012). Penelitian Pendidikan Metode dan Paradigma
Baru, Bandung: PT Remaja Rosdakarya. 